\title{
Correlation of histological grade with Estrogen, Progesterone and HER2/neu reactivity in breast cancer
}

\author{
Girishma Shrestha ${ }^{1,2}$, Bandana Satyal ${ }^{1,3}$, Palzum Sherpa ${ }^{2}$ \\ ${ }^{I}$ Intrepid Cancer Diagnostics, Kathmandu, Nepal \\ ${ }^{2}$ Department of Pathology, Patan Academy of Health Sciences, Lalitpur, Nepal. \\ ${ }^{3}$ Department of Pathology, B\&B Hospital, Lalitpur, Nepal
}

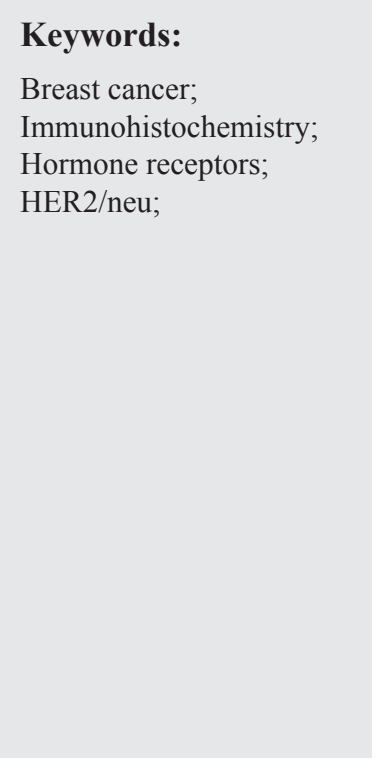

\begin{abstract}
Background: Treatment modalities and prognosis of breast carcinoma depend largely on their hormone receptors (Estrogen and Progesterone Receptors) and HER2/neu profile. Various studies conducted within Nepal have highlighted their overall status in breast carcinomas but studies on their correlation with histological grade are few. This study aims to correlate hormone receptors and HER2/neu status with different histological grades of invasive breast carcinoma.
\end{abstract}

Materials and Methods: This is a retrospective analysis of cases received at Intrepid Cancer Diagnostics, Nepal between January 2015 to December 2018 for evaluation of status of hormonal receptors and HER2/ neu on invasive breast carcinomas. Mastectomy and excisional biopsies were included for statistical correlation between hormone receptors, HER2/neu and histological grades $(n=364) . P-$ value $<=0.01$ was considered statistically significant.

Results: Of 364 invasive carcinomas categorized into grades 1, 2 and 3, Estrogen Receptor positivity was noted in 77.3\% (34/44), 60.8\% (115/189) and 28.2\% (37/131) respectively; Progesterone Receptor positivity was noted in $61.4 \%$ (27/44), 52.4\% (99/189) and 21.4\% (28/131) respectively; HER2/neu positivity was noted in $18.2 \%(8 / 44), 20.1 \%(38 / 189)$ and $19.8 \%(26 / 131)$ respectively. Triple negativity was found to be $9.1 \%(4 / 44), 21.7 \%(41 / 189)$ and $41.9 \%(55 / 131)$ in grade 1,2 and 3 carcinomas respectively.

Conclusions: Estrogen and Progesterone receptor expressing carcinomas were found to be more often of grade 1 category, with this rate declining through grades 2 and 3. No such correlation was noted for HER2/neu. Triple negative carcinomas were found to be of higher grade (grade 3).

\section{Correspondence:}

Dr. Girishma Shrestha, MD

Department of Pathology

Patan Academy of Health Sciences, Lalitpur, Nepal

ORCID ID: https://orcid.org/0000-0002-1660-6694

Email: girishma.path@gmail.com

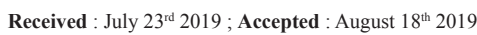

Citation: Shrestha G, Sigdel B, Shrepa P. Correlation of histological grade with Estrogen, Progesterone and HER2/neu reactivity in breast cancer. J Pathol Nep 2019;9:1518-22. DOI 10.3126/jpn.v9i2.24963

Copyright: This is an open-access article distributed under the terms of the Creative Commons Attribution 4.0 International License, which permits unrestricted use, distribution, and reproduction in any medium, provided the original author and source are credited.

\section{INTRODUCTION}

Breast cancer is the most commonly diagnosed cancer and the leading cause of cancer death among females worldwide. ${ }^{1}$ As per GLOBOCAN 2018 database, breast cancer ranks as the fifth leading cause of death (627000 deaths, $6.6 \%)$ and prognosis is considered to be relatively favourable in developed countries. ${ }^{2}$ In Nepal, breast cancer accounts for $11.6 \%$ of all the cancer related deaths in women, ranking third after cervical and lung cancers. ${ }^{3}$ 
All invasive breast carcinomas are routinely graded based on histological features, such as tubule/gland formation, nuclear pleomorphism and mitotic count. Significant association between histological grade and survival of patients has been demonstrated and it remains an independent prognostic factor for estrogen-receptor (ER) positive carcinomas. ${ }^{4-6}$ Independent studies have highlighted negative relationship of ER/PR status with histological grade and similarly HER2/neu expression more in higher grade carcinomas. ${ }^{7-12}$

Assessment of hormone receptors and HER2/neu provides prognostic as well as predictive information on response to endocrine therapy and anti-HER2 targeted therapy respectively, and have become established procedures in routine management. ${ }^{13}$ This study was carried out to analyze correlation of ER and Progesterone (PR) receptors, HER2/ neu status among different histological grades of invasive breast carcinomas.

\section{MATERIALS AND METHODS}

This is a retrospective study of cases received from January 2015 to December 2018 at Intrepid Cancer Diagnostics. All cases received between January 2015 to December 2018 for evaluation of ER, PR and HER2/neu status were included.

Formalin fixed paraffin embedded tissues were received. $4 \mu \mathrm{m}$ sections were cut and slides were stained with Hematoxylin \& Eosin (H\&E) for morphological evaluation. Sections were evaluated by two pathologists and morphological interpretation, histological typing was done based on World Health Organization classification of tumors of breast. ${ }^{6}$ All cases of invasive carcinoma were histologically graded according to Elston-Ellis modification of the ScarffBloom-Richardson grading system (Nottingham grading system). ${ }^{14,15}$

Further sections were obtained on poly-L-lysine coated slides and processed for immunohistochemistry using Dako / Agilent antibodies with antigen-antibody streptavidin- biotin technique. Allred/Quick scoring system was used for interpretation of ER and PR. ${ }^{6}$ ASCO/CAP guideline was used for assessment of HER2/neu overexpression pattern on immunohistochemistry. ${ }^{16}$

Overall status of ER, PR, HER2/neu and triple negativity was analyzed among all cases of invasive breast carcinomas. Correlation between histological grade and immunohistochemical profile was evaluated on excisional biopsies and mastectomy specimens, that comprised 364 cases, while trucut biopsies, small biopsies, metastatic lesions were not included for this correlation. Statistical analysis was done using Statistical package for social sciences (SPSS) software, version 21. Chi-square test was used and P-value $\leq 0.01$ was considered statistically significant.

\section{RESULTS}

Total 477 cases of invasive breast carcinoma were received between January 2015 to December 2018 for evaluation of ER, PR, HER2/neu status. Patients' age ranged from 22 to 91 years with mean age at diagnosis being 50 years and median age 48 years. 469 (98.3\%) were female, while 8 $(1.7 \%)$ were male. Slight predominance of left breast was noted (54.3\% left, $45.7 \%$ right).

Distribution of hormone receptors and HER2/neu status among different histological types of invasive carcinoma and their overall status are shown in tables 1 and 2. Among 8 male patients (Table 3), all $8(100 \%)$ and $7(87.5 \%)$ showed ER and PR positivity respectively. HER2/neu was uniformly negative and none showed triple negative status.

Out of 477 cases of invasive carcinomas, mastectomy and excisional biopsy specimens accounted for 364 cases and only these were included for statistical correlation between histological grade and ER, PR, HER2neu status.

Table 4 shows distribution of ER, PR, HER2/neu and triple

Table 1: Distribution of hormone receptors and HER2/neu status among various histological types of invasive carcinomas

\begin{tabular}{|c|c|c|c|c|}
\hline Histological Type & $\begin{array}{c}\text { ER } \\
\text { Positive (\%) }\end{array}$ & $\begin{array}{c}\text { PR } \\
\text { Positive (\%) }\end{array}$ & $\begin{array}{c}\text { HER2 } \\
\text { Positive (\%) }\end{array}$ & Total \\
\hline Invasive carcinoma of no special type & $224(52)$ & $188(43.6)$ & $80(18.6)$ & 431 \\
\hline Carcinoma with medullary features & $1(11.1)$ & $0(0)$ & $1(11.1)$ & 9 \\
\hline Invasive carcinoma, NST with apocrine differentiation & $0(0)$ & $0(0)$ & $2(22.2)$ & 9 \\
\hline Invasive lobular carcinoma & $9(100)$ & $9(100)$ & $2(22.2)$ & 9 \\
\hline Invasive carcinoma, NST with mucinous component & $7(100)$ & $7(100)$ & $0(0)$ & 7 \\
\hline Mixed invasive carcinoma, NST and lobular carcinoma & $1(25)$ & $1(25)$ & $1(25)$ & 4 \\
\hline Invasive papillary carcinoma & $2(100)$ & $1(50)$ & $1(50)$ & 2 \\
\hline Metaplastic carcinoma & $0(0)$ & $0(0)$ & $1(50)$ & 2 \\
\hline Mucinous carcinoma & $2(100)$ & $2(100)$ & $0(0)$ & 2 \\
\hline Invasive carcinoma, NST with neuroendocrine differentiation & $1(100)$ & $1(100)$ & $0(0)$ & 1 \\
\hline Secretory carcinoma & $1(100)$ & $0(0)$ & $0(0)$ & 1 \\
\hline
\end{tabular}


Table 2: Overall distribution of hormone receptors and HER2/neu status among all invasive carcinomas

\begin{tabular}{lcccc} 
& ER (\%) & PR (\%) & HER2/neu (\%) & $\begin{array}{c}\text { TRIPLE } \\
\text { NEGATIVE }\end{array}$ \\
\hline Positive & $248(52)$ & $209(43.8)$ & $88(18.4)$ & \\
Negative & $229(48)$ & $268(56.2)$ & $297(62.3)$ & \\
\hdashline Indeterminate & - & - & $92(19.3)$ & $128(26.8 \%)$ \\
\hline Total & $\mathbf{4 7 7}$ & $\mathbf{4 7 7}$ & & \\
\hline
\end{tabular}

Table 3: Distribution pattern of hormone receptors and HER2/neu status in male patients

\begin{tabular}{|c|c|c|c|c|}
\hline & ER (\%) & PR (\%) & HER2/neu (\%) & $\begin{array}{c}\text { TRIPLE } \\
\text { NEGATIVE }\end{array}$ \\
\hline Positive & $8(100)$ & $7(87.5)$ & $0(0)$ & \multirow{3}{*}{$0(0)$} \\
\hline Negative & $0(0)$ & $1(12.5)$ & $8(100)$ & \\
\hline Total & 8 & 8 & 8 & \\
\hline
\end{tabular}

Table 4: Distribution of hormone receptors and HER2/neu status among invasive carcinomas of different histological grades and their statistical correlation.

\begin{tabular}{|c|c|c|c|c|c|}
\hline Histological grade & $\begin{array}{l}\text { ER Positive } \\
\text { n (\%) }\end{array}$ & $\begin{array}{l}\text { PR Positive } \\
\text { n (\%) }\end{array}$ & $\begin{array}{c}\text { HER2/neu Positive } \\
\text { n (\%) }\end{array}$ & $\begin{array}{c}\text { Triple Negative } \\
\text { n (\%) }\end{array}$ & Total \\
\hline Grade 1 & $34(77.3)$ & $27(61.4)$ & $8(18.2)$ & $4(9.1)$ & 44 \\
\hline Grade 2 & $115(60.8)$ & $99(52.4)$ & $38(20.1)$ & $41(21.6)$ & 189 \\
\hline Grade 3 & $37(28.2)$ & $28(21.4)$ & $26(19.8)$ & $55(41.9)$ & 131 \\
\hline p-value & $<=0.01$ & $<=0.01$ & $>0.05$ & $<=0.01$ & - \\
\hline Total & 186 & 154 & 72 & 100 & 364 \\
\hline
\end{tabular}

Table 5: Hormone receptor and HER2/neu status identified in various studies

\begin{tabular}{|c|c|c|c|c|c|}
\hline Author & No. of cases & $\mathrm{ER}+(\%)$ & $P R+(\%)$ & HER2/neu+ (\%) & Triple Negative (\%) \\
\hline Nepal $B^{12}$ & 97 & 46.9 & 48.9 & 28.9 & 23 \\
\hline Singh Shrestha $\mathbf{J}^{18}$ & 124 & 39.51 & 37.89 & 60.3 & 32.87 \\
\hline Thapa $B^{24}$ & 262 & 46.9 (ER\&/or PR) & - & 24.0 & 15.3 \\
\hline Pathak TB $^{20}$ & 131 & 27.94 & 19.11 & - & - \\
\hline Dayal A ${ }^{7}$ & 80 & 56.9 & 35.5 & 21.3 & - \\
\hline Muhammad K ${ }^{25}$ & 396 & 32 & 29.7 & - & - \\
\hline Jovici $\mathbf{M}^{9}$ & 80 & 71.3 & 60 & - & - \\
\hline Emmanuel I ${ }^{10}$ & 96 & 36.5 & 28.6 & 33.3 & 41.3 \\
\hline Geethamala $K^{8}$ & 100 & 54 & 52 & 25 & 20 \\
\hline Current study & 477 & 52 & 43.8 & 18.4 & 26.8 \\
\hline
\end{tabular}

negativity status among invasive carcinomas of different histological grades. Statistically significant correlation was noted for ER and PR with lower grade carcinomas expressing hormone receptors more often than higher grade carcinomas. No such statistical significance was noted for HER2/neu. Significant correlation with histological grade was noted for triple negative tumors.

\section{DISCUSSION}

In present study, mean age of patients was 50 years with peak distribution among 45-55 years age group, comparable to other studies done within Nepal. ${ }^{17,18}$

Overall rate of ER/PR positivity $(52 \% / 43.8 \%)$ is similar to findings of Geethamala K $(54 \% / 52 \%)$, Dayal A
$(56.9 \% / 35.5 \%)$ and Nepal B (46.9\% / 48.9\%) in studies conducted within Nepal as well as neighboring Asian countries. ${ }^{7,8,19}$ Analysis of various other studies done within Nepal reveal ER/PR positivity status ranging from $20 \%$ to 48.9 percent. ${ }^{17-20}$ This finding, however, is different from studies done primarily in western, more developed regions, where positivity was found to be high, as much as $80 \%{ }^{6,21}$ Same holds true for PR, for which positivity was noted upto $70 \%{ }^{6}$ The differing results raise the possibility of different genetic signature of breast cancers occurring among women of Asian population.

With respect to correlation of the histological grade with hormone receptors and HER2/neu status, most grade 1 carcinomas were ER/PR positive, while reverse held true for grade 3 carcinomas with $p$-value $\leq 0.01$. Finding is in 
Table 6: Distribution of hormone receptors and HER2/neu status among different histological grades identified in various studies

\begin{tabular}{|c|c|c|c|c|c|c|c|c|c|c|}
\hline \multirow[t]{3}{*}{ Author } & \multirow[t]{3}{*}{ No. of cases } & \multicolumn{9}{|c|}{ Correlation with histological grade } \\
\hline & & \multicolumn{3}{|c|}{ Grade I } & \multicolumn{3}{|c|}{ Grade II } & \multicolumn{3}{|c|}{ Grade III } \\
\hline & & $\begin{array}{l}\text { ER+ } \\
(\%)\end{array}$ & $\begin{array}{l}\text { PR+ } \\
(\%)\end{array}$ & $\begin{array}{c}\text { HER+ } \\
(\%)\end{array}$ & $\begin{array}{c}\text { ER+ } \\
(\%)\end{array}$ & $\begin{array}{l}\text { PR+ } \\
(\%)\end{array}$ & $\begin{array}{c}\text { HER+ } \\
(\%)\end{array}$ & $\begin{array}{l}\text { ER+ } \\
(\%)\end{array}$ & $\begin{array}{c}\text { PR+ } \\
(\%)\end{array}$ & $\begin{array}{c}\text { HER+ } \\
(\%)\end{array}$ \\
\hline Muhammad $K^{25}$ & 195 & 19 & 17.9 & - & 38 & 36.0 & - & 33 & 28.4 & - \\
\hline Jovici $\mathbf{M}^{9}$ & 80 & 100 & 100 & - & 76.4 & 61.6 & - & 41.2 & 35.3 & - \\
\hline Emmanuel I ${ }^{10}$ & 96 & 33.3 & 27.8 & 27.78 & 37.9 & 27.6 & 41.4 & 37.5 & 31.3 & 25.0 \\
\hline Nisa $A^{11}$ & 150 & 70 & 70 & 0 & 48.2 & 36.1 & 22.9 & 3.5 & 1.8 & 31.6 \\
\hline Pathak TB ${ }^{20}$ & 131 & 59.3 & 37 & - & 26.3 & 18.8 & - & 3.4 & 3.4 & - \\
\hline Mittal A ${ }^{26}$ & 62 & 26 & 26 & - & 4 & 4 & - & 1 & 2 & - \\
\hline Geethamala $\mathbf{K}^{8}$ & 100 & 84.2 & 78.9 & 15.8 & 66.7 & 64.9 & 27.8 & 7.4 & 7.4 & 26.4 \\
\hline Current Study & 364 & 77.3 & 61.4 & 18.2 & 60.8 & 52.4 & 20.1 & 28.2 & 21.4 & 19.8 \\
\hline
\end{tabular}

agreement with that elucidated by many other studies..$^{8,9,20,22}$ This concurs with the accepted fact that ER, PR positive carcinomas tend to be of good prognosis and likewise, more of them would fall in grade 1 category.

No significant correlation was noted between HER2/neu and histological grade with $18.2 \%, 20.1 \%$ and $19.8 \%$ positivity in grade 1, 2 and 3 respectively, similar to studies conducted by Dayal A, Geethamala K and Emmanuel. ${ }^{7,8,10}$ Findings appear to vary among studies, some exhibiting significant correlation. $^{11,12}$ It does seem likely that carcinomas with HER2/neu positivity would cluster more in grade 3 category, considering HER2/neu positivity signify a poorer prognosis. It's apt to point out the limitation of this study with this regard, as fluorescence in situ hybridization (FISH) analysis for HER2/neu overexpression on indeterminate cases could not be done due to financial constraints and results could have varied if otherwise.

Triple negative breast cancers constituted $26.8 \%$ overall, with increasing trend from grade 1 through grade 3 invasive carcinomas (Table 4). Studies conducted within Nepal show triple negative cancers to range from $15.3 \%$ up to $41.3 \%$. $(17,18,20,23,24)$ Studies have shown that triple negative carcinomas vary with ethnicity and have documented a higher incidence in African women compared to Caucasians. ${ }^{10,12}$

\section{CONCLUSIONS}

Immunohistochemical profile of different histological grades and types of invasive carcinomas in current study appear similar to those conducted in Indian subcontinent. However, studies from western, more developed regions show higher percentage of ER/PR positive carcinomas, indicating a possible differing gene signature of breast carcinomas occurring within Nepal and nearby Asian countries. Proper identification of HER2/neu overexpression by FISH is strongly recommended for all cases that show indeterminate IHC staining pattern.

\section{Acknowledgment}

Authors would like to express sincere gratitude to Ms. Manju Bajracharya for technical support.

\section{Conflict of interests: None}

\section{REFERENCES}

1. Bray F, Ferlay J, Soerjomataram I, Siegel RL, Torre LA, Jemal A. Global cancer statistics 2018: GLOBOCAN estimates of incidence and mortality worldwide for 36 cancers in 185 countries. CA Cancer J Clin. 2018 Nov;68(6):394-424. Crossref

2. IARC. Latest Global Cancer Data, 2018. World Heal Organ [Internet]. 2018;(September):13-5. Crossref

3. World Health Organization - Cancer Country Profiles, 2014. Crossref

4. Rakha EA, El-Sayed ME, Menon S, Green AR, Lee AHS, Ellis IO. Histologic grading is an independent prognostic factor in invasive lobular carcinoma of the breast. Breast Cancer Res Treat. 2008;111(1):121-7. Crossref

5. Rakha EA, El-Sayed ME, Lee AHS, et al. Prognostic Significance of Nottingham Histologic Grade in Invasive Breast Carcinoma. J Clin Oncol 2008;26(19):3153-8. $\underline{\text { Crossref }}$

6. S.R L, Ellis IO, Schnitt S j., Tan PH, van de Vijver MJ. WHO Classification of Tumours of the Breast [Internet]. 4th ed. IARC. IARC: Lyon 2012; 2012. $\underline{\text { Crossref }}$

7. Dayal A, Shah RJ, Kothari S, Patel SM. Correlation of Her-2/neu status with estrogen, progesterone receptors and histologic features in breast carcinoma. Ann Pathol Lab Med. 2016;3(5):A-476- 83. $\underline{\text { Crossref }}$

8. Geethamala K, V SM, Vani BR, Rao S. Histopathological Grade Versus Hormone Receptor Status In Breast Carcinoma- Treasure The Past. International Journal of Biomedical Research: 2015; 6(07): 466-71. DOI: $\underline{\text { Crossref }}$ 
9. Jovici M, Ili R, Kati V, Zivkovi V. Correlation of steroid hormone receptor status with histological and nuclear grad- ing in breast carcinoma. 2004;173-7. Crossref

10. Emmanuel I, M. Mandong B, V. Kwaghe B, Yakubu D. Estrogen receptor, progesterone receptor, and human epidermal growth factor receptor-2 status of breast cancers in women visiting the Jos university teaching hospital. Ann Niger Med. 2018;11(1):22-6. $\underline{\text { Crossref }}$

11. Nisa A, Bhurgri Y, Raza F, Kayani N. Comparison of ER, PR \& HER-2 / neu ( C-erb B 2 ) Reactivity Pattern with Histologic Grade, Tumor Size and Lymph Node Status in Breast Cancer. Asian Pacific J Cancer Prev. 2008;9:553-6 $\underline{\text { Crossref }}$

12. Ambroise M, Ghosh M, Mallikarjuna VS, Kurian A. Immunohistochemical profile of breast cancer patients at a tertiary care hospital in South India. Asian Pac J Cancer Prev. 2011;12(3):6259. $\underline{\text { Crossref }}$

13. Ellis IO, Lee AHS, Pinder SE, Rakha EA. Tumors of the breast. In: Fletcher CDM, editor. Diagnostic histopathology of tumors. 4th ed. 2013. p. 1113-8.

14. Bloom HJ, Richardson WW. Histological grading and prognosis in breast cancer; a study of 1409 cases of which 359 have been followed for 15 years. Br J Cancer. 1957;11(3):359-77. Crossref

15. Elston CW, Ellis IO. Pathological prognostic factors in breast cancer. I. The value of histological grade in breast cancer: experience from a large study with long-term follow-up. C. W. Histopathology 1991; 19; 403-10. $\underline{\text { Crossref }}$

16. Wolff AC, Hammond MEH, Schwartz JN, et al. American Society of Clinical Oncology/College of American Pathologists guideline recommendations for human epidermal growth factor receptor 2 testing in breast cancer. Arch Pathol Lab Med. 2007;131(1):18-43. DOI: $\underline{\text { Crossref }}$

17. Acharya, S., Jha, A., \& Manandhar, T. Clinical profile of patients presenting with breast cancer in Nepal. Kathmandu Univ Med J. 2012;10(39):3-7. Crossref
18. Singh Shrestha J, Shrestha A, Shrestha S, Shrestha S, Sharma TR, Maskey R. Epidemiology and Clinical Profile of Breast Cancer in Central Nepal. Ann Breast Cancer Res. 2016;1(1):1-5. Crossref

19. Nepal B, Singh Y, Sayami P, Sayami G. An institutional review of tumour biology of breast cancer in young Nepalese women. J Soc Surg Nepal. 2015;18(2):16-9. Crossref

20. TB P, Bashyal R, Cb P, Shrestha S, et al. Estrogen and progesterone receptor expression in breast carcinoma. 2011;1:100-3. Crossref

21. Sheikhpour E, Taghipour S. The Differences of Age, Tumor Grade, and Her2 Amplification in Estrogen and Progesterone Receptor Status in Patients with Breast Cancer. Int J Cancer Manag. 2018 Feb 28;11(8):8-11. Crossref

22. Putti TC, El-Rehim DMA, Rakha EA, Paish CE, Lee AH, Pinder $\mathrm{SE}$, et al. Estrogen receptor-negative breast carcinomas: a review of morphology and immunophenotypical analysis. Mod Pathol. 2005;18(1):26-35. Crossref

23. Chinnam A, Naidu S, Gurram H, Chaganti PD. Immunohistochemical profile of breast carcinomas in correlation with histological grade experience of a tertiary care hospital in Andhra Pradesh. Natl J Med Res. 2015;5(4):275-7. Crossref

24. Thapa B, Singh Y, Sayami P, Shrestha UK, Sapkota R, Sayami G. Breast Cancer in Young Women from a Low Risk Population in Nepal. Asian Pacific J Cancer Prev. 2013;14(9):5095-9. $\underline{\text { Crossref }}$

25. Muhammad K, Imran K, Hasna H, Mrinal B, Gurjeet K, Rajajul I. Association of Carcinoma Breast: Grade and Estrogen Progesterone Receptor Expression. J Coll Physicians Surg Pakistan. 2010;20(4):250-2. Crossref

26. Mittal A, Prasad C, Pn S, Srinivasan D, Joshi RU. Histopathological Grade versus Estrogen and Progestron Receptor Status in Carcinoma Breast- A Single Center Study. Open Access J Surg. 2017;4(3):10-3. Crossref 